\title{
PERBANDINGAN HASIL BELAJAR BACA TULIS AL-QUR'AN DENGAN MENGGUNAKAN METODE CERAMAH PLUS DAN METODE MAKE A MATCH DI MTS AVICENNA SUNAN BONANG
}

\author{
Abdul Basyit \\ abdulbasyit@umt.ac.id \\ (Fakultas Agama Islam, Universitas Muhammadiyah Tangerang) \\ Sahlani \\ Sahlaros44yahoo.com \\ (Fakultas Agama Islam, Universitas Muhammadiyah Tangerang) \\ Lisnina Suherna \\ lisninaasuherna@gmail.com \\ (Program Studi Pendidikan Agama Islam, Fakultas Agama Islam, Universitas \\ Muhammadiyah Tangerang)
}

\begin{abstract}
Abstrak
Pendidik sebagai salah satu unsur dalam pendidikan yang mempunyai peranan penting dalam mewujudkan tujuan pembelajaran. Penguasaan materi saja tidak cukup, seorang pendidik harus menguasai berbagai metode pembelajaran yang tepat sesuai materi yang akan diajarkan. Dalam dunia pendidikan umumnya dan khususnya proses pendidikan, penggunaan metode pembelajaran yang tepat sangat penting diperhatikan, karena keberhasilan proses pendidikan tergantung pada cocok tidaknya metode yang digunakan dalam pembelajaran. Maka dari itu dalam penelitian ini peneliti menggunakan perbandingan antara metode pembelajaran Ceramah plus Diskusi dan Tugas dengan metode Pembelajaran Make a Match untuk mengetahui metode mana yang lebih baik untuk meningkatkan hasil belajar siswa. Hasil penelitian ini menunujukkan bahwa $t_{\text {hitung }}=3,361>t_{\text {tabel }}=1,672$ sehingga ada perbedaan hasil belajar siswa antara kelas yang menggunakan metode Ceramah plus Diskusi dan Tugas dengan kelas yang menggunakan metode Make a Match pada mata pelajaran Baca Tulis Al-Qur'an kelas VIII di MTs Avicenna Sunan Bonang Tangerang. Berdasarkan rata-rata hasil belajar kelas eksperimen adalah 76,86. Sedangkan rata-rata hasil belajar kelas kontrol 71,33, sehingga rata-rata kelas eksperimen > kelas kontrol. Besarnya pengaruh kelas eksperimen dan kelas kontrol terhadap hasil belajar siswa yaitu 75,90\%.
\end{abstract}

\section{Kata Kunci: Metode Ceramah Plus, Metode Make a Match, Hasil Belajar}

Abstract

Educators as one of the elements in education have an important role in realizing learning goals. Mastery of the material is not enough, an educator must master various learning methods that are appropriate to the material to be taught. In the world of education in general and in particular the educational process, the use of appropriate learning methods is very important, because the success of the educational process depends on whether the methods used in learning are suitable. Therefore, in this study the researcher used a comparison between the Lecture plus learning method and the Make a Match learning method to find out which method was better for improving student learning outcomes. Hypothesis testing is done by using the Independent Sample T-Test. The results of this study show that $t_{\text {count }}=3,361>t_{\text {table }}=1,672$ so that there are differences in student learning 
outcomes between classes using the Lecture plus Discussion and Assignment methods and those using the Make a Match method in the class VIII class of reading and writing Al-Qur'an at MTs Avicenna Sunan Bonang Tangerang. Based on the average learning outcomes of the experimental class is 76,86. While the average learning outcomes of the control class are 71,33, so the average experimental class > control class. The magnitude of the influence of the experimental class on student learning outcomes is 75,90\%.

\section{Keywords: Lecture Plus Method, Make a Match Methode, Learning Outcomes}

\section{A. Pendahuluan}

Pendidikan adalah usaha manusia (pendidik) untuk dengan penuh tanggung jawab membimbing anak-anak didik ke kedewasaan. ${ }^{1}$ Proses pendidikan tersusun atas sejumlah komponen atau unsur yang saling berkaitan dan saling berinteraksi satu sama lain, interaksi antara pendidik dan peserta didik pada saat proses belajar mengajar berlangsung memegang peran penting sehingga mencapai hasil belajar yang diharapkan. Untuk melaksanakan suatu strategi digunakan seperangkat metode pengajaran tertentu. Dalam pengertian demikian maka metode pengajaran menjadi salah satu unsur dalam strategi belajar mengajar. ${ }^{2}$ Dalam dunia pendidikan umumnya dan khususnya proses pendidikan, penggunaan metode pembelajaran yang tepat sangat penting diperhatikan karena keberhasilan proses pendidikan tergantung pada cocok tidaknya metode yang digunakan dalam pembelajaran.

Rendahnya kualitas hasil belajar siswa disebabkan oleh dua faktor, yaitu faktor intern dan faktor ekstern. Faktor intern yaitu faktor yang dialami dan dihayati siswa yang berpengaruh pada proses dan hasil belajar, sedangkan faktor ekstern meliputi hal-hal seperti guru

${ }^{1}$ Sumadi Suryabrata, Psikologi Pendidikan (Jakarta: PT Rajagrafindo Persada, 2013), Cet. Ke20, h. 293

${ }^{2}$ Abdul Majid, Belajar dan Pembelajaran Pendidikan Agama Islam, (Bandung: PT Remaja Rosdakarya, 2014), h.131-132 sebagai pembina belajar, prasarana dan sarana pembelajaran, kebijakan penilaian, lingkungan sosial siswa di sekolah dan rumah, kurikukulum sekolah, serta metode-metode pembelajaran yang digunakan oleh guru. ${ }^{3}$

Pada saat ini kurikulum yang sedang dikembangkan di Indonesia yaitu kurikulum 2013, Pembelajaran dalam Kurikulum 2013 lebih menekankan pada pembelajaran kontekstual dengan student center, dan pendekatan ilmiah. Ketiga penekanan tersebut dalam pelaksanaannya menuntut guru untuk dapat secara aktif mendayagunakan lingkungan sebagai sumber belajar. $^{4}$ Diantara banyaknya metode-metode pembelajaran yang ada dalam meningkatkan hasil belajar siswa seperti metode ceramah plus dan metode make a match. Metode ceramah plus adalah metode mengajar yang menggunakan lebih dari satu metode, yakni metode ceramah gabung dengan metode lainnya. ${ }^{5}$ Sedangkan Make a Match adalah siswa diminta mencari pasangan kartu yang merupakan jawaban atau pertanyaan materi tertentu dalam pembelajaran. Salah satu keunggulan teknik ini adalah siswa mencari pasangan sambil belajar mengenai suatu konsep atau

\footnotetext{
${ }^{3}$ Dimyati dan Mujiono, Belajar dan Pembelajaran, (Jakarta: Rineka Cipta, t.t), h. 260

${ }^{4}$ E. Mulyasa, Guru dalam Implementasi Kurikulum 2013 (Bandung: PT Remaja Rosdakarya, 2016), Cet. Ke-3, h. 131

${ }^{5}$ Zakiah Daradjat, Metodik Khusus Pengajaran Agama Islam (Jakarta: PT Bumi Aksara), h. 201-203
} 
topik dalam suasana yang menyenangkan. ${ }^{6}$ Namun, metode pembelajaran make a match jarang di aplikasikan karena metode pembelajaran make a match butuh banyak waktu dan persiapan dalam pelaksanaannya.

Pendidikan Baca Tulis Al-Qur'an dimaksudkan untuk memberikan motivasi, bimbingan, pemahaman, kemampuan dan penghayatan terhadap isi yang terkandung dalam Al-Qur'an. ${ }^{7}$ Oleh karena itu, dalam melakukan pengajaran baca tulis al-qur'an, perlu menggunakan metode-metode yang tepat dalam pelaksanaannya. Hal tersebut dimaksudkan agar pengajaran bisa efektif dan efisien sehingga peserta didik akan lebih cepat dalam menguasai materi yang disampaikan. Dilihat dari latar belakang yang penulis paparkan permasalahan yang ingin diteliti adalah metode manakah yang tepat untuk pembelajaran Baca Tulis AlQur'an dari kedua metode yang penulis paparkan yaitu metode Ceramah plus Diskusi dan Tugas dengan metode Make a Match.

Penelitian ini akan memaparkan Bagaimana hasil belajar Metode Ceramah plus Diskusi dan Tugas dengan Metode Make a Match terkait pembelajaran Baca Tulis Al-Qur'an bagi peserta didik kelas VIII di MTs Avicenna Sunan Bonang. Apakah penggunaan Metode Ceramah plus Diskusi dan Tugas dengan Metode Make a Match dapat diterapkan dalam pembelajaran Baca Tulis Al-Qur'an pada peserta didik kelas VIII di MTs Avicenna Sunan Bonang?. Apakah penggunaan metode pembelajaran Make a Match lebih baik dibanding dengan metode pembelajaran Ceramah plus Diskusi dan

${ }^{6}$ Aris Shoimin, 68 Model Pembelajaran Inovatif dalam Kurikulum 2013 (Yogyakarta: ArRuzz Media,2018), cet-2, h. 48

7 A. Rosyid, Pandai Baca Tulis dan Tahfiz. Al-Qur'an untuk Siswa SMP VII (t.tp, Erlangga, 2014), h. 8
Tugas pada mata pelajaran Baca Tulis AlQur'an?.

\section{B. Metode Penelitian}

Penelitian ini menggunakan metode penelitian kuantitatif dengan penelitian eksperimen kuasi (Quasi Experimental). Metode kuantitatif dapat diartikan sebagai metode penelitian yang berlandaskan pada filsafat positivisme, digunakan untuk meneliti pada populasi atau sampel tertentu, pengumpulan data menggunakan instrumen penelitian, analisis data bersifat kuantitatif/statistik. ${ }^{8}$ Quasi experimental disebut juga eksperimen semu. Eksperimen kuasi banyak digunakan dalam penelitian pendidikan. ${ }^{9}$

Penelitian ini menguji perbandingan Variabel X1 (Metode Ceramah plus Diskusi dan Tugas) dan Variabel X2 (Metode Make a Match) terhadap Variabel Y (Hasil Belajar).

1. Populasi dan Teknik Pengambilan Sampel

a. Populasi, Populasi adalah totalitas semua nilai yang mungkin baik hasil menghitung maupun hasil mengukur baik kualitatif maupun kuantitatif dari karakteristik mengenai sekumpulan objek yang lengkap dan jelas. ${ }^{10}$ Adapun yang menjadi populasi pada penelitian ini adalah peserta didik MTs Avicenna Sunan Bonang Tangerang Tahun 2020/2021, dengan jumlah keseluruhan 210 siswa.

b. Sampel, Penentuan sampel pada penelitian ini menggunakan teknik

${ }^{8}$ Sugiyono, Metode Penelitian Kombinasi (Mix Methods) (Bandung: Alfabeta, 2016), Cet ke8 , h. 11

${ }^{9}$ Zainal Arifin, Penelitian Pendidikan Metode dan Paradigma Baru (Bandung: PT Remaja Rosdakarya, 2014), Cet. Ke-3, h.74

${ }^{10}$ Purwanto, Metodologi Penelitian Kuantitatif untuk Psikologi dan Pendidikan (Yogyakarta: Pustaka Pelajar, 2015), Cet. Ke-4, h. 241 
sampling purposive yaitu penentuan sampel dengan pertimbangan tertentu. ${ }^{11}$ Sampel diambil sebanyak dua kelas, yaitu satu kelas sebagai kelas eksperimen dan satu kelas lagi sebagai kelas kontrol, jumlah peserta didik kedua kelas tersebut sebanyak 60 siswa.

\section{Teknik Pengumpulan Data}

Adapun metode pengumpulan data yang digunakan adalah:

a. Observasi, Instrumen observasi akan lebih efektif jika informasi yang hendak diambil berupa kondisi atau fakta alami, tingka laku dan hasil kerja responden dalam situasi alami. ${ }^{12}$ Dalam observasi ini peneliti lebih banyak menggunakan salah satu dari panca indranya yaitu indra penglihatan

b. dokumentasi, Sejumlah besar fakta dan data tersimpan dalam bahan yang berbentuk dokumentasi.Sebagian besar data yang tersedia adalah berbentuk surat-surat, catatan harian, cendera mata, laporan, artefak, foto, dan sebagainya. $^{13}$

c. Tes, Tes adalah serangkaian pertanyaan yang digunakan untuk mengukur keterampilan, pengetahuan atau bakat yang dimiliki individu atau kelompok. ${ }^{14}$

d. Wawancara. Wawancara digunakan sebagai teknik pengumpulan data apabila ingin melakukan studi

\footnotetext{
${ }^{11}$ Sugiyono, Metode Penelitian Kuantitatif, Kualitatif, dan R\&D (Bandung: CV Alfabeta, 2018), Cet. Ke-27, h.85

${ }^{12}$ Sukardi, Metodologi Penelitian Pendidikan Kompetensi dan Praktiknya (Jakarta: PT Bumi Aksara, 2017), Cet. Ke-16, h. 78-79

${ }^{13}$ Zainal Arifin, Penelitian Pendidikan Metode dan Paradigma baru (Bandung: PT Remaja Rosdakarya, 2014), Cet.ke-3, h.171

${ }^{14}$ Andra Tersiana, Metode Penelitian (Yogyakarta: Start Up, 2018), Cet. Ke-1, h. 86
}

pendahuluan untuk menemukan permasalahan yang harus diteliti. ${ }^{15}$

\section{Teknik Analisis Data}

Dalam penelitian ini penulis ingin menguji perbedaan dua rata-rata dari dua sampel tentang suatu variabel yang diteliti, maka teknik statistik yang digunakan adalah uji-t (t-test). Asumsi penggunaan Uji $-t$ adalah:

a. Uji Normalitas, Uji normalitas bertujuan untuk mengetahui distribusi data dalam variabel yang akan digunakan dalam penelitian. Data yang baik dan layak digunakan dalam penelitian adalah data yang memiliki distribusi normal. Normalitas data dapat dilihat dengan menggunakan uji normal Kolmogorov-Smirnov. ${ }^{16}$ Dasar pengambilan keputusannya adalah Jika Sig. > 0,005 maka data berdistribusi normal.

b. Uji Homogenitas, Uji homogenitas digunakan untuk menguji apakah varians kedua data sampel (kelas kontrol dan kelas eksperimen) data homogen atau tidak. Ketentuan pengujian ini adalah Jika nilai Sig. atau nilai probabilitas $>0.05$ maka data bervarian sama atau homogen.

c. Independent Sample T-Test, Independent Sample T-Test digunakan untuk menguji signifikansi beda ratarata dua kelompok. Uji ini digunakan untuk mengetahui perbedaan metode ceramah plus diskusi dan tugas dengan metode make a match terhadap hasil belajar Baca Tulis Al-Qur'an (BTQ) peserta didik. Dalam menguji hipotesis ini peneliti juga menggunakan program aplikasi SPSS for windows versi 22.

\footnotetext{
${ }^{15}$ Sugiyono, Metode Penelitian Kuantitatif, Kualitatif, dan R\&D...., h. 137-138

${ }^{16} \mathrm{~V}$. Wiratna Sujarweni, SPSS Untuk Penelitian (Yogyakarta: Pustaka Baru Press, 2015), h. 52
} 
d. Hipotesis Statistik

Jika Sig. $<0.05$, maka $H_{O}$ ditolak dan $H_{a}$ diterima

jika Sig. > 0.05, maka $H_{0}$ diterima dan $H_{a}$ ditolak

$H_{0}=$ Tidak terdapat perbedaan yang signifikan

$H_{a}=$ Terdapat perbedaan yang signifikan

\section{Hasil Penelitian Dan Pembahasan}

1. Metode Ceramah plus Diskusi dan Tugas

a. Pengertian Metode Pembelajaran Ceramah plus Diskusi dan Tugas

Metode ceramah adalah bentuk interaksi melalui penerangan dan penuturan lisan dari guru kepada peserta didik, ceramah juga sebagai kegiatan memberikan informasi dengan kata-kata yang sering mengaburkan dan kadang-kadang ditafsirkan salah. ${ }^{17}$ Agar pendidik dapat memanfaatkan keunggulan metode ceramah dan sekaligus mengurangi kelemahan metode ini, sebaiknya diterapkan kombinasi metode ceramah dengan metode yang lain, inilah yang dimaksud dengan metode ceramah plus yaitu ada tambahan metode-metode lain dalam penyampaian materi.Contoh macam-macam metode ceramah plus adalah Metode Ceramah plus Tanya Jawab dan Tugas (CPTT), Metode Ceramah plus Diskusi dan Tugas (CPDT), Metode Ceramah plus Demonstrasi dan Latihan (CPDL) ${ }^{18}$ Metode ceramah plus diskusi dan tugas (CPDT), metode ini dilakukan secara tertib sesuai dengan urutan

\footnotetext{
${ }^{17}$ Tukiran Taniredja, dkk., Model-Model Pembelajaran Inovatif dan Efektif (Bandung: Alfabeta, 2015), Cet ke-6, h. 45

${ }^{18}$ Zakiah Daradjat, Metodik Khusus Pengajaran Agama Islam (Jakarta: PT Bumi Aksara), h. 201-203
}

pengkombinasiannya, yaitu pertama guru menguraikan materi pelajaran kemudian mengadakan diskusi, dan akhirnya memberi tugas. ${ }^{19}$

b. Kelebihan dan Kekurangan Metode Ceramah plus. Kelebihan metode ini adalah kelas lebih aktif karena siswa tidak mendengarkan saja, Dengan metode ceramah plus ini guru bisa mengontrol urutan dan keluasan materi pembelajaran, sehingga dapat mengetahui sejauh mana siswa menguasai bahan pelajaran yang disampaikan. Kekurangan dari metode ini adalah Dengan adanya tanya jawab kadang-kadang menyimpang dari pokok persoalan bila dalam mengajukan pertanyaan, siswa menyinggung hal-hal lain walaupun masih ada hubungannya dengan pokok yang dibicarakan. Dalam hal ini sering tidak terkendalikan sehingga memunculkan persoalan baru. Metode ini bisa menjadi ceramah murni jika seorang guru tidak cermat dalam penggunaan metode ini. Memerlukan waktu yang cukup banyak. ${ }^{20}$

2. Metode Pembelajaran Make a Match

a. Pengertian Metode Make a Match. Dikembangkan pertama kali pada 1994 oleh Lorna Curran, Strategi Make a match saat ini menjadi salah satu strategi penting dalam ruang kelas. Tujuan dari strategi ini antara lain: pendalaman materi, penggalian materi, dan edutainment. ${ }^{21}$ Make a match yaitu

\footnotetext{
${ }^{19}$ Trianto, Mengembangkan Model Pembelajaran Tematik (Jakarta: PT Prestasi Pustaka, 2010), Cet. Ke-1, h. 135-136

${ }^{20}$ Hana Maurin dan Sani Insan Muhamadi, "Metode Ceramah Plus Diskusi dan Tugas Untuk Meningkatkan Aktifitas Belajar Siswa," Jurnal Of Islamic Primary Education, 2018, h. 66

${ }^{21}$ Miftahul Huda, Model-Model Pengajaran dan Pembelajaran Isu-Isu Metodis dan Paradigmatis (Yogyakarta: Pustaka Pelajar, 2017), Cet. Ke-6, h. 251
} 
metode pembelajaran dimana guru menyiapkan kartu yang berisi persoalan-permasalahan dan kartu yang berisi jawabannya, setiap siswa mencari dan mendapatkan sebuah kartu soal dan berusaha menjawabnya, setiap siswa mencari kartu jawaban yang cocok dengan persoalannya. ${ }^{22}$ Jadi dapat disimpulkan bahwa penerapan Metode Make a Match ini dimulai dengan teknik yaitu peserta didik diminta mencari pasangan yang merupakan jawaban atau pertanyaan yang telah diberikan oleh pendidik. Dalam strategi pembelajaran ini siswa dituntut untuk menguasai dan memahami konsep melalui pencarian kartu, dimana kartu tersebut terdiri dari dua bagian yaitu kartu soal dan kartu jawaban. Setiap siswa memiliki kesempatan untuk memperoleh satu buah kartu.

b. Kelebihan dan Kekurangan Metode Make a Match. Kelebihannya metode ini yaitu Dapat meningkatkan aktivitas belajar siswa, baik secara kognitif maupun fisik, karena ada unsur permainan metode ini sangat menyenangkan, Meningkatkan pemahaman siswa terhadap materi yang dipelajari dan dapat meningkatkan motivasi belajar siswa, Efektif sebagai sarana melatih keberanian siswa untuk tampil presentasi. Adapun kelemahannya yaitu Jika strategi ini tidak dipersiapkan dengan baik, akan banyak waktu yang terbuang. Pada awal-awal penerapan metode, banyak siswa yang akan malu berpasangan dengan lawan jenisnya. Jika guru tidak mengarahkan siswa dengan baik, akan banyak siswa

\footnotetext{
${ }^{22}$ Ngalimun, Strategi dan Model Pembelajaran (Yogyakarta: Aswaja Pressindo, 2018), Cet. Ke-2, h. 243-244
}

yang kurang memperhatikan pada saat presentasi pasangan. ${ }^{23}$

3. Hasil Belajar

Gagne mengemukakan bahwa "Learning is change in human disposition or capacity, which pesrsists over a period time, and which is not simply ascribable to process a growth." Artinya belajar adalah perubahahan yang terjadi dalam kemampuan manusia setelah belajar secara terus menerus, bukan hanya disebabkan proses pertumbuhan saja. ${ }^{24}$ Sudijono mengungkapkan hasil belajar merupakan sebuah tindakan evaluasi yang dapat mengungkapkan aspek proses berpikir (cognitive domain) juga dapat mengungkap aspek kejiwaan lainnya, yaitu aspek nilai atau sikap (affective domain), dan aspek keterampilan (psychomotor domain) yang melekat pada diri setiap individu peserta didik. ${ }^{25}$ Jadi dapat disimpulkan bahwa hasil belajar adalah kemampuan yang didapat dalam proses belajar mengajar dan menghasilkan perubahan perilaku secara keseluruhan pada peserta didik dalam ketiga ranah pendidikan yaitu ranah kognitif, afektif, dan psikomotor.

Pengujian Persyaratan Analisis

Penelitian ini untuk mengetahui perbandingan hasil belajar Baca Tulis AlQur'an yang menggunakan metode ceramah plus diskusi dan tugas dengan metode make a match, untuk mendapat gambaran dan data-datanya sebelumnya peneliti mengadakan observasi dan

${ }^{23}$ Miftahul Huda, Model-Model Pengajaran dan Pembelajaran ..., h. 253-254

${ }^{24}$ Asis Saefudin dan Ika Berdiati, Pembelajaran Efektif (Bandung: PT Remaja Rosdakarya, 2016), Cet.ke-3, h.8

${ }^{25}$ Valiant Lukad Perdana Sutrisno, Jurnal Pendidikan Vokasi, No. 01/Vol. 6, Februari 2016, h. 114 
pengumpulan data dengan cara wawancara terhadap tiga narasumber yang berada di ruang lingkup sekolah dan melaksanakan pembelajaran via aplikasi zoom serta memberikan tes kepada siswa. Dalam penelitian yang dilakukan, peneliti menggunakan alat ukur tes hasil belajar siswa pada mata pelajaran Baca Tulis AlQur'an (BTQ).

1. Hasil Belajar Siswa. Pada kelas eksperimen dari 30 siswa yang melaksanakan tes hasil belajar didapatkan 2 orang siswa hasilnya sangat baik, 22 orang siswa mendapatkan hasil baik dan 6 orang mendapatkan hasil cukup. Sedangkan pada kelas kontrol dari 30 siswa 17 orang siswa mendapatkan hasil cukup, 13 orang siswa mendapatkan hasil baik. Dapat disimpulkan bahwa metode pembelajaran make a match dan metode ceramah plus diskusi dan tugas dapat di terapkan di dalam kegiatan belajar mengajar pada mata pelajaran Baca Tulis Al-Qur'an (BTQ) karena nilai siswa rata-ratanya berkategori cukup, baik dan sangat baik. Berdasarkan hasil wawancara dengan guru Baca Tulis Al-Qur'an bahwa metode pembelajaran ceramah plus diskusi dan tugas dengan metode make a match memang sangat cocok diterapkan baik bagi siswa yang lambat maupun siswa yang sudah aktif karena mampu mendorong semua siswa ikut serta berperan dalam pembelajaran. ${ }^{26}$

2. Uji Normalitas. Dari hasil output Test of Normality Kolmogorov-Smirnov pada perhitungan dengan menggunakan program SPSS didapatkan hasil kelas eksperimen Sig. 0,071 > 0,05 dan di kelas kontrol di dapatkan hasil Sig.

${ }^{26}$ Lampiran hasil wawancara 20 juli 2020 dengan gubid Baca Tulis Al-Qur'an MTs Avicenna Sunan Bonang
$0,077>0,05$ yang artinya kedua data berdistribusi normal.

3. Uji Homogenitas. Dari hasil pengujian homogenitas didapatkan hasil Sig. $0.344>0.05$ maka dapat disimpulkan bahwa data bervarian sama atau homogen. Sehingga analisis selanjutnya bisa dilanjutkan.

\section{Pengujian Hipotesis}

Pengujian ini menggunakan uji beda atau independen samples $t$ test, untuk menguji hipotesis ini peneliti menggunakan bantuan program SPSS 22.0 for windows dan didapatkan hasil pada equal variance assumed diperoleh nilai $t_{\text {hitung }}=3,361>t_{\text {tabel }}=1,672$ dan pada kolom Sig. (2-tailed) didapatkan hasil $0.001<0.05$, maka dapat diambil keputusan yaitu Jika Sig. (2-tailed) < 0.05, maka $H_{0}$ ditolak dan $H_{a}$ diterima yang artinya Terdapat perbedaan hasil belajar siswa antara kelas yang menggunakan metode Ceramah Plus Diskusi dan Tugas dengan kelas yang menggunakan metode Make a Match pada mata pelajaran Baca Tulis Al-Qur'an kelas VIII di MTs Avicenna Sunan Bonang Tangerang.

Diperoleh nilai mean (nilai rata-rata hasil belajar siswa) pada kelas Eksperimen sebesar 76,866 dan kelas Kontrol sebesar 71,333. Dimana kelas eksperimen ini menggunakan metode pembelajaran make a match dan kelas kontrol menggunakan metode pembelajaran ceramah plus diskusi dan tugas. Dengan demikian dapat dikatakan bahwa tingkat hasil belajar Baca Tulis Al-Qur'an (BTQ) antara siswa yang menggunakan metode make a match lebih tinggi daripada siswa dengan menggunakan metode ceramah plus diskusi dan tugas.

\section{Kesimpulan}

Berdasarkan paparan data dan pembahasan pada bab IV serta berdasarkan 
perumusan masalah yang ada pada tahap awal penelitian, maka dapat diambil kesimpulan sebagai berikut:

1. Metode pembelajaran ceramah plus diskusi dan tugas dengan metode pembelajaran make a match dapat diterapkan dalam proses pembelajaran Baca Tulis Al-Qur'an pada kelas VIII MTs Avicenna Sunan Bonang, dilihat dari hasil belajar yang berkategori cukup, baik dan sangat baik serta dari hasil wawancara dengan guru Baca Tulis Al-Qur'an menurut beliau kedua metode ini sangat baik diterapkan pada mata pelajaran Baca Tulis Al-Qur'an.

2. Hasil belajar siswa dengan menggunakan metode pembelajaran Ceramah plus Diskusi dan Tugas pada mata pelajaran Baca Tulis Al-Qur'an kelas VIII 2, berdasarkan hasil penelitian termasuk dengan kategori Cukup. Hal ini dibuktikan dengan diketahui hasil dari perhitungan rataratanya adalah 71,333 sedangkan hasil belajar siswa dengan menggunakan metode pembelajaran Make a Match pada kelas VIII 1 dikategorikan Baik, hal ini dibuktikan dengan hasil dari perhitungan rata-ratanya sebesar 76,866 .

3. Berdasarkan pada perhitungan uji hipotesis dengan uji independent sample t-test didapatkan hasil Sig. (2tailed) $0.001<0.05$ dimana pengujian hipotesis tersebut berarti $H_{0}$ ditolak dan $H_{a}$ diterima, yaitu Terdapat perbedaan hasil belajar siswa antara kelas yang menggunakan metode Ceramah plus Diskusi dan Tugas dengan kelas yang menggunakan metode Make a Match pada mata pelajaran Baca Tulis AlQur'an kelas VIII di MTs Avicenna Sunan Bonang Tangerang
Arifin, Zainal. 2014. Penelitian Pendidikan Metode dan Paradigma Baru. Bandung: PT Remaja Rosdakarya

Daradjat, Zakiah. Metodik Khusus Pengajaran Agama Islam. Jakarta: PT Bumi Aksara

Dimyati dan Mujiono. Belajar dan Pembelajaran. Jakarta: Rineka Cipta

Huda, Miftahul. 2017. Model-Model Pengajaran dan Pembelajaran IsuIsu Metodis dan Paradigmatis. Yogyakarta: Pustaka Pelajar

Lukad Perdana Sutrisno, Valiant. 2016. Jurnal Pendidikan Vokasi, No. 01/Vol. 6

Majid, Abdul. 2014. Belajar dan Pembelajaran Pendidikan Agama Islam. Bandung: PT Remaja Rosdakarya

Maurin, Hana dan Sani Insan Muhamadi. 2018. "Metode Ceramah Plus Diskusi dan Tugas Untuk Meningkatkan Aktifitas Belajar Siswa," Jurnal Of Islamic Primary Education

Mulyasa, E. 2016. Guru dalam Implementasi Kurikulum 2013. Bandung: PT Remaja Rosdakarya

Ngalimun. 2018. Strategi dan Model Pembelajaran. Yogyakarta: Aswaja Pressindo

Purwanto. 2015. Metodologi Penelitian Kuantitatif untuk Psikologi dan Pendidikan. Yogyakarta: Pustaka Pelajar

Rosyid, A. 2014. Pandai Baca Tulis dan Tahfiz Al-Qur'an untuk Siswa SMP VII. Erlangga

Saefudin, Asis dan Ika Berdiati. 2016. Pembelajaran Efektif. Bandung: PT Remaja Rosdakarya

Shoimin, Aris. 2018. 68 Model Pembelajaran Inovatif dalam Kurikulum 2013. Yogyakarta: ArRuzz Media

\section{DAFTAR PUSTAKA}


Sukardi. 2017. Metodologi Penelitian Pendidikan Kompetensi dan Praktiknya. Jakarta: PT Bumi Aksara Suryabrata, Sumadi. 2013. Psikologi Pendidikan. Jakarta: PT Rajagrafindo Persada

Sugiyono. 2016. Metode Penelitian Kombinasi (Mix Methods). Bandung: Alfabeta.

------. 2018. Metode Penelitian Kuantitatif, Kualitatif, dan $R \& D$. Bandung: CV Alfabeta

Taniredja, Tukiran, dkk. 2015. ModelModel Pembelajaran Inovatif dan Efektif. Bandung: Alfabeta

Tersiana, Andra. 2018. Metode Penelitian. Yogyakarta: Start Up

Trianto. 2010. Mengembangkan Model Pembelajaran Tematik. Jakarta: PT Prestasi Pustaka
Wiratna Sujarweni,V. 2015. SPSS Untuk Penelitian. Yogyakarta: Pustaka Baru Press 
Perbandingan Hasil Belajar Baca Tulis Al-Qur'an Dengan Menggunakan Metode Ceramah Plus Dan Metode Make A Match Di Mts Avicenna Sunan Bonang 